\title{
An Asymmetric Vinylogous Michael Cascade of Silyl Glyoximide, Vinyl Grignard, and Nitroalkenes via Long Range Stereoinduction
}

\author{
Gregory R. Boyce ${ }^{\dagger}$ and Jeffrey S. Johnson ${ }^{\ddagger},{ }^{*}$ \\ tDepartment of Chemistry and Physics, Florida Gulf Coast University, Fort Myers, Florida 33965, \\ United States \\ ‡Department of Chemistry, University of North Carolina, Chapel Hill, North Carolina 27599-3290, \\ United States
}

\section{Abstract}

A diastereoselective auxiliary-mediated vinylation/[1,2]-Brook rearrangement/vinylogous Michael cascade of silyl glyoximide, vinylmagnesium bromide, and nitroalkenes is described. The reaction occurs with complete regio- and diastereocontrol in good yield. The diastereoselectivity is induced by a rare instance of 1,7-chirality transfer that is hypothesized to arise from a trans-multiheterodecalin transition state.

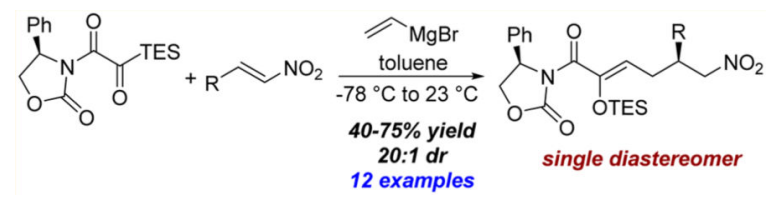

\begin{abstract}
Vinylogous reactivity provides a distinct and atom economical approach for the direct $\gamma$ functionalization of carbonyls to synthesize complex targets. Prototypical cases involve the conversion of $\alpha, \beta$-unsaturated carbonyls to their derived dienolates, or synthetic equivalents thereof, and electrophilic trapping at the $\gamma$-carbon. Although the vinylogous Mukaiyama aldol $^{1}$ and Mannich ${ }^{2}$ reactions have become well-established, the vinylogous Michael reaction has received less attention. ${ }^{3}$ A key selectivity issue is the site of trapping in the extended $\pi$-system. Computational studies of frontier orbital densities and HOMO coefficients of simple lithium metallodienolates have established that a-trapping is favored over the $\gamma$-position. ${ }^{1 \mathrm{a}, 4}$ The majority of examples of the vinylogous Michael reaction rely on substrates with an inherent preference for $\gamma$-selectivity relative to a-trapping: butenolides or a,a-dicyanoalkenes are commonly used. ${ }^{2}$
\end{abstract}

\footnotetext{
*Corresponding Author. jsj@unc.edu.

ASSOCIATED CONTENT

Supporting Information

The Supporting Information is available free of charge on the ACS Publications website at DOI: 10.1021/acs.joc.5b02693.

Copies of the ${ }^{1} \mathrm{H}$ and ${ }^{13} \mathrm{C}$ NMR spectra and HPLC traces (PDF)
} 
Despite these challenges, some impressive examples of $\gamma$-functionalization via the vinylogous Michael reaction have been reported with various latent nucleophiles in the past five years. In 2010, Melchiorre and co-workers demonstrated that 3-alkylcyclohex-2-en-1ones could be employed as competent nucleophiles in highly regio- and enantioselective organocatalytic vinylogous Michael reactions with $\beta$-nitrostyrenes. ${ }^{5}$ Jørgenson then demonstrated the use of enals as acyclic latent dienolates in reactions with a-keto esters to construct dihydropyrans via formal $[4+2]$ cycloaddition. ${ }^{6}$ Linear vinylogous Michael products were developed independently by $\mathrm{Schnieder}^{7}$ and $\mathrm{Xu}^{8}$ that expanded the vinylogous Mukaiyama Michael reaction (VMMR) to include aromatic $\alpha, \beta$-unsaturated ketones with enals to provide valuable 1,7-dioxo compounds. In 2013, Wang and coworkers described (salen)Mg-catalyzed vinylogous Michael additions between $\beta$-alkyl chalcones and $\beta$-nitrostyrenes to give nitrocyclohexanols in a formal $[4+2]$ cycloaddition. $^{9}$ In general, the integration of functionality at the a-position is challenging, and the cases described above all rely on deprotonation of a latent dienolate precursor (Figure 1).

In 2010, we reported an alternative approach to the vinylogous Michael reaction by achieving the requisite dienolate via a vinylation/[1,2]-Brook rearrangement ${ }^{11}$ of silyl glyoxylates. The latter are a reliable class of conjunctive reagents for the union of nucleophilic and electrophilic partners. ${ }^{10}$ The title reaction was envisioned based on the seminal publications by the Kuwajima and Reich groups on silyloxyallyl- and silyloxypropargyl anionic systems. ${ }^{12}$ Addition of vinyl Grignard ${ }^{11}$ or acetylide $^{13}$ nucleophiles to silyl glyoxylates create $(Z)$-glycolate enolates ${ }^{14}$ that can either engage a secondary electrophile with either $\alpha$ - or $\gamma$-trapping. The identity of the secondary electrophile employed in silyl glyoxylate couplings functions as a regiochemical switch: carbonyl electrophiles provide predominantly a-adducts, ${ }^{15}$ whereas nitroalkenes and cyanoolefins provide exclusively $\gamma$-addition via trapping of an unusual a-keto ester homoenolate synthetic equivalent. Although the vinylogous Michael methodology provided good yields and complete regioselectivity favoring the $\gamma$-adduct, the utility was limited by the lack of stereoselectivity in forming the new chiral center.

Inducing asymmetry in the three-component couplings of silyl glyoxylates has been a topic of significant interest with instructive examples highlighted in Figure 2. Useful levels of diastereoselectivity (dr 15:1) were initially realized in the tandem Oppenauer oxidation/aldol reaction using an 8-phenylmenthol auxiliary. Although this result demonstrates that a chiral auxiliary at the ester moiety can provide high levels of selectivity, the selectivity was highly substrate dependent and could not be developed to include a wider scope. ${ }^{16} \mathrm{Schmitt}$ et al. found similar substrate dependence in the glycolate Michael reaction: 5:1 diastereoselection was imparted by the chiral auxiliary. In independent reports, Greszler et al. ${ }^{17}$ and Yao and $\mathrm{Lu}^{18}$ demonstrated that chiral electrophiles can successfully provide high levels of stereoinduction via a proposed chairlike transition state. After several of our attempts to accomplish the vinylogous Michael cascade asymmetrically with silyl glyoxylate and chiral catalysts failed, a suitable chiral auxiliary was sought to confer asymmetry. Silyl glyoximides, a new class of acyl silanes developed by Hsung and co-workers, held promise as asymmetric conjunctive reagents. ${ }^{19}$ 
Herein, we describe vinylation-initiated vinylogous Michael cascades of silyl glyoximides, nitroalkenes, and vinylmagnesium bromide. This work builds upon the initial finding reported in the original three-component coupling of silyl glyoxylates, vinyl Grignard, and nitroalkenes. ${ }^{11}$ The disclosed methodology affords (Z)-enolsilanes with complete regio- and diastereoselectivity by exploiting a rare example of long-range 1,7-chirality transfer to provide complete asymmetric induction. Compared to other vinylogous Michael methodologies, silyl glyoximides offer a conceptually distinct approach to the requisite dienolate nucleophile via a [1,2]-Brook rearrangement ${ }^{20}$ that provides a-heteroatom functionality currently inaccessible through other methods (Scheme 1). The threecomponent coupling yields densely functionalized compounds, providing an enolsilane, nitro group, and acyl oxazolidinone ${ }^{21}$ in the product.

Because the synthesis of the desired silyl glyoximide $\mathbf{1}$ has been reported to provide a low yield, ${ }^{19}$ we sought to optimize the sequence (Scheme 2). We employed the aerobic oxidative carbamoylation protocol of Stahl and co-workers, ${ }^{22}$ which utilized a 5-fold excess of the oxazolidinone to provide a significant increase in yield from 23 to $74 \%$. The excess of the oxazolidinone is required to inhibit homocoupling of the TES-alkyne; however, because the excess is not consumed in the reaction, the oxazolidinone can be recovered by flash chromatography. For the subsequent oxidation of the ynamide to the imido acyl silane, the reported $5 \mathrm{~mol} \%$ catalyst loading was examined to minimize the use of the ruthenium complex. For this substrate, the catalyst loading could be decreased from 5 to $1 \mathrm{~mol} \%$ of ruthenium(IV) oxide hydrate without adversely affecting the yield (81\%). This two-step synthesis provides a $60 \%$ overall yield of the imido acyl silane, which compares favorably to the synthesis of the original silyl glyoxylate reagent. ${ }^{23}$

With a reliable synthesis of the primary electrophile in hand, the feasibility of the title process was investigated. An initial reaction of the imido acyl silane, $\beta$-nitrostyrene, and vinyl Grignard at $-78^{\circ} \mathrm{C}$ followed by warming to room temperature provided the desired three-component coupling product $\mathbf{3 a}$ in $47 \%$ yield as a single diastereomer. The absolute configuration was determined by conversion to the known $\gamma$-nitroaldehyde by ozonolysis. ${ }^{24}$ Analysis of the byproducts demonstrated that vinylmagnesium bromide acts as a highly discriminating nucleophile in this reaction manifold with a strong preference for the acyl silane over the nitroalkene secondary electrophile: only trace quantities of direct Grignard addition to the nitroalkene were observed. Optimization revealed that a $50 \%$ excess of the nitroalkene improves the yield of the coupling to $75 \%$. Unlike the related silyl glyoxylate coupling that required excess silyl glyoxylate to compensate for oligomerization, ${ }^{11}$ the imido acyl silane coupling produces no observable oligomerization. This absence of oligomerization may be due to several factors, including the added steric bulk of the chiral auxiliary and the altered electronics of the dienolate. The ( $Z$ )-geometry of the enolsilane was determined by analogy to the related enolsilanes from the silyl glyoxylate vinylogous Michael cascade. ${ }^{11}$ This $(Z)$-selectivity is also consistent with the homoenolate precedent set by the research groups of Reich and Kuwajima. ${ }^{12,14}$

With suitable conditions in hand, an examination of the allowable steric and electronic parameters of the coupling in the nitroalkene component was undertaken. A variety of alkyl, alkenyl, aryl, and heteroaryl nitroalkenes were submitted to the reaction conditions, and the 
results are compiled in Table 1 . The yields of three-component coupling products ranged from 40 to $75 \%$ with the ortho-substituted $\beta$-nitrostyrene substrates providing the lowest yields. Alkyl-, alkenyl-, and heteroaromatic-substituted nitroalkenes, as well as the piperonal-derived $\mathbf{3 f}$ and cinnamaldehyde-derived $\mathbf{3 i}$, were well-tolerated. Nitrodiene $\mathbf{3 i}$ exhibited 1,4-selectivity in the face of potentially competing 1,6-addition, a circumstance that may provide a hint to the operative transition state of the three-component coupling (vide infra). All examples provided greater than 20:1 diastereoselectivity as judged by ${ }^{1} \mathrm{H}$ NMR spectroscopic analysis of the unpurified reaction mixture. a-Substituted Grignard reagents (e.g., 2-propenylmagnesium bromide) were attempted, but productive threecomponent coupling was not observed.

With high levels of stereoinduction for the vinylation coupling, we sought to utilize the silyl glyoximide to impart facial selectivity into the three-component alkynyl coupling previously reported by our group. ${ }^{13}$ Substituting the vinyl Grignard with an alkynyl Grignard was demonstrated to produce stereodefined silyloxyallenes $\mathbf{4}$ in a highly diastereoselective manner as illustrated in Scheme 3. Density functional theory (DFT) calculations supported a highly organized closed transition state where chelation between the nitro group and the metallodienolate enabled a fixed approach of the electrophile with respect to the (Z)glycolate enolate. Exposing the silyl glyoximide to the reported coupling conditions provided 5 as a 1:1 mix of two (of four possible) diastereomers (as judged by ${ }^{1} \mathrm{H}$ NMR spectroscopic analysis of the unpurified reaction mixture).

Because 1,7-chiral induction is rare, ${ }^{25}$ we sought to understand the transition state that imparts such a high level of diastereoselectivity. A chelation-controlled model for this coupling would rely on nitroalkene activation by the Lewis acidic ${ }^{+} \mathrm{MgBr}$ portion of the (Z)metallodienolate to guide the approach of the former. We invoked a strong coordination effect of the nitro group to the magnesium counterion in a related silyl glyoxylate coupling with acetylides that was corroborated by DFT-calculations. This coordination was further empirically supported by the inability of a poor chelator, benzylidenemalononitrile, to perform with the same level of selectivity in the reaction. ${ }^{13}$ The electron-rich oxazolidinone can form a six-membered chelate to the magnesium counterion to provide rigidity and enforce facial selectivity from the oxazolidinone stereocenter. The nitroalkene approach can then be directed by coordination to the Lewis acid, creating a trans-decalin transition state 6 as shown in Figure 3.

Significant precedent exists for such decalin transition states when multiple electronic interactions are possible. ${ }^{26}$ The multiheterobicyclo[4.4.0]decane framework of the transition state relies on the electrostatic interaction between the nitrogen and the electron-dense aposition of the (Z)-metallodienolate. This orientation should also enable a stabilizing $\pi_{\mathrm{C}}=\mathrm{C}$ $\rightarrow \pi^{*} \mathrm{~N}=\mathrm{O}$ interaction. This transition state would place the substituent of the nitroalkene into a desirable pseudoequatorial position that leads to the observed stereoisomer.

The three-component coupling of silyl glyoximide, vinylmagnesium bromide, and nitroalkenes to provide $(Z)$-enolsilanes with exceptional diastereoselectivity and good yields for a diverse substrate scope is disclosed. The high level of stereoinduction arising from a long-range 1,7-chiral transfer is hypothesized to be a result of a highly organized trans- 
decalin transition state. This reactivity pattern offers a unique complement to known acyclic vinylogous Michael methodologies by providing access to a-substituted linear products with a densely functionalized core. The (Z)-stereochemistry of the enolsilane prevents the Henry cyclization observed by Wang and co-workers, enabling the isolation of linear vinylogous products for the first time.

\section{EXPERIMENTAL SECTION}

\section{General Information}

Proton and carbon nuclear magnetic resonance spectra $\left({ }^{1} \mathrm{H}\right.$ and $\left.{ }^{13} \mathrm{C} N \mathrm{NR}\right)$ were recorded at 600 and $150 \mathrm{MHz}$, respectively, with solvent resonance as the internal standard $\left({ }^{1} \mathrm{H}\right.$ NMR: $\mathrm{CDCl}_{3}$ at $7.26 \mathrm{ppm} ;{ }^{13} \mathrm{C} \mathrm{NMR:} \mathrm{CDCl}_{3}$ at $\left.77.0 \mathrm{ppm}\right) .{ }^{1} \mathrm{H}$ NMR data are reported as follows: chemical shift, multiplicity $(\mathrm{s}=$ singlet, $\mathrm{d}=$ doublet, $\mathrm{dd}=$ doublet of doublets, $\mathrm{t}=$ triplet, $\mathrm{q}=$ quartet, $\mathrm{m}=$ multiplet), coupling constants $(\mathrm{Hz})$, and integration. Mass spectra were obtained using an FT-ICR mass analyzer with electrospray ionization. TLC visualization was accomplished with UV light and/or either aqueous potassium permanganate $\left(\mathrm{KMnO}_{4}\right)$ or aqueous ceric ammonium molybdate (CAM) solution followed by heating. All reactions were carried out under an atmosphere of nitrogen in ovendried glassware with magnetic stirring. Yield refers to isolated yield of analytically pure material. Yields are reported for a specific experiment and as a result may differ slightly from those found in the tables, which are averages of at least two experiments. Dichloromethane, tetrahydrofuran, and toluene were dried by passage through a column of neutral alumina under nitrogen prior to use. ${ }^{27}$

Triethylsilyl Silyl Glyoximide (1)—Sodium carbonate (118.7 mg, $1.12 \mathrm{mmol}, 2$ equiv), $\mathrm{CuCl}_{2}$ (15.0 mg, $0.112 \mathrm{mmol}, 0.2$ equiv), and $(R)$-4-phenyloxazolidin-2-one (455.0 mg, 2.79 mmol, 5 equiv) were added to an oven-dried round-bottom flask. The reaction flask was purged with $\mathrm{O}_{2}$ three times prior to the addition of toluene $(3 \mathrm{~mL}, 0.2 \mathrm{M})$ and pyridine $(0.09$ $\mathrm{mL}, 1.12 \mathrm{mmol}, 2$ equiv). A balloon of $\mathrm{O}_{2}$ was attached, and the reaction flask was placed in a preheated $70{ }^{\circ} \mathrm{C}$ oil bath. (Triethylsilyl)acetylene $(0.10 \mathrm{~mL}, 0.56 \mathrm{mmol}, 1$ equiv) in toluene ( $3 \mathrm{~mL}, 0.2 \mathrm{M}$ ) was added dropwise over $6 \mathrm{~h}$ via syringe pump. The reaction was allowed to stir for $16 \mathrm{~h}$ and then cooled to room temperature and filtered through Celite. The crude mixture was concentrated in vacuo and then purified by flash chromatography with $25 \%$ EtOAc/hexanes to afford the requisite ynamide in $78 \%$ yield. The ynamide stains best with $\mathrm{KMnO}_{4}$ and ultraviolet light. The unreacted oxazolidinone can be recovered and reused by flushing the column with $100 \%$ EtOAc. The ynamide ( $390.0 \mathrm{mg}, 1.29 \mathrm{mmol}, 1$ equiv) was then treated with $\mathrm{NaIO}_{4}\left(830.0 \mathrm{mg}, 3.88 \mathrm{mmol}, 3\right.$ equiv) and $\mathrm{RuO}_{2}$ hydrate $(1.7 \mathrm{mg}, 0.013$ mmol, 0.01 equiv) in a dichloromethane/acetonitrile/water $(14 \mathrm{~mL}, 2 / 2 / 3 \mathrm{v} / \mathrm{v})$ solution. The reaction was vigorously stirred for $3 \mathrm{~h}$ at room temperature, filtered through Celite, and concentrated in vacuo. The crude mixture was purified via silica plug $(100 \%$ dichloromethane) to afford $370.0 \mathrm{mg}(86 \%)$ of product 1 as a yellow solid. The title compound's properties matched the reported characterization data. ${ }^{15}$

General Procedure for Synthesis of Nitroalkenes (2a-2l). ${ }^{28 a}$-To the appropriate aldehyde $(14.2 \mathrm{mmol})$ were added $2 \mathrm{~mL}$ of nitromethane and $25 \mathrm{~mL}$ of $\mathrm{MeOH}$. This solution was cooled to $0{ }^{\circ} \mathrm{C}$, and $35 \mathrm{~mL}$ of $1 \mathrm{M} \mathrm{NaOH}$ solution was added portionwise. The solution 
was allowed to stir for $2 \mathrm{~h}$ and warm to room temperature. The mixture was then slowly added to an aqueous $6 \mathrm{M} \mathrm{HCl}$ solution cooled to $0{ }^{\circ} \mathrm{C}$ and stirred for $15 \mathrm{~min}$. The mixture was washed with dichloromethane $(3 \times 15 \mathrm{~mL})$. The organic layers were combined, washed with brine, dried over $\mathrm{Na}_{2} \mathrm{SO}_{4}$, and concentrated in vacuo. The crude mixture was purified by flash chromatography ( $10 \% \mathrm{EtOAc/hexanes)}$ to afford the desired nitroalkene in yields ranging from 40 to $80 \%$ depending on the substrate. ${ }^{1} \mathrm{H}$ NMR spectral data matched those reported in the literature. ${ }^{28}$

General Procedure for the Synthesis of Enolsilanes (3a-3l)-The silyl glyoximide and nitroalkene were added to an oven-dried vial. The vial was then purged with $\mathrm{N}_{2}$, and toluene $(0.1 \mathrm{M})$ was added. The resulting solution was cooled to $-78^{\circ} \mathrm{C}$ using an acetone/dry ice bath, and vinylmagnesium bromide was added dropwise to the solution. Once the addition was complete, the reaction was allowed to warm to room temperature and stirred for $1 \mathrm{~h}$; it was then diluted with diethyl ether $(5 \mathrm{~mL})$ and quenched with saturated ammonium chloride $(5 \mathrm{~mL})$. The resulting mixture was stirred for $10 \mathrm{~min}$. The layers were separated, and the aqueous layer was extracted with ethyl acetate $(3 \times 10 \mathrm{~mL})$. The organic extracts were combined, washed with brine $(5 \mathrm{~mL})$, dried with magnesium sulfate, and concentrated in vacuo. The crude mixture was purified by flash chromatography $(25 \%$ EtOAc/hexanes) to afford products $\mathbf{3 a - 1}$

(R)-3-((S,Z)-6-Nitro-5-phenyl-2-((triethylsilyl)oxy)hex-2-enoyl)-4-phenyloxazolidin-2one (3a): The title compound was prepared according to the general procedure using imide 1 (50.0 mg, $0.150 \mathrm{mmol}, 1.0$ equiv), nitroalkene $2 \mathbf{a}^{28 \mathrm{a}}$ (33.6 mg, $\left.0.225 \mathrm{mmol}, 1.5 \mathrm{equiv}\right)$, and vinylmagnesium bromide $(0.23 \mathrm{~mL}, 0.230 \mathrm{mmol}, 1.5$ equiv), affording $57.4 \mathrm{mg}(75 \%)$ of the product as a yellow oil. Analytical data for 3a: IR (thin film, $\mathrm{cm}^{-1}$ ) 3436, 3064, 3032, 2957, 2913, 2877, 1785, 1692, 1644, 1552, 1381, 1320, 1204, 1157; ${ }^{1} \mathrm{H} \mathrm{NMR}$ (400 MHz, $\left.\mathrm{CDCl}_{3}\right) \delta 7.41-7.24(\mathrm{~m}, 10 \mathrm{H}), 5.51-5.47(\mathrm{~m}, 2 \mathrm{H}), 4.75-4.63(\mathrm{~m}, 3 \mathrm{H}), 4.26(\mathrm{dd}, J=8.4,7.2$ $\mathrm{Hz}, 1 \mathrm{H}), 3.70-3.62(\mathrm{~m}, 1 \mathrm{H}), 2.71-2.55(\mathrm{~m}, 2 \mathrm{H}), 0.97(\mathrm{dd}, J=8,7.6 \mathrm{~Hz}, 9 \mathrm{H}), 0.67$ (q, $J=8$ $\mathrm{Hz}, 6 \mathrm{H}) ;{ }^{13} \mathrm{C} \mathrm{NMR}\left(100 \mathrm{MHz}, \mathrm{CDCl}_{3}\right) \delta 165.9,153.0,144.6,139.3,137.2,129.1,129.0$, $128.9,127.7,127.3,126.4,117.9,79.5,69.8,58.5,43.5,29.6,6.5,5.2$; TLC (20\% EtOAc/ hexanes) $R_{f} 0.36$; HRMS (ESI ${ }^{+}$) calcd for $\mathrm{C}_{27} \mathrm{H}_{34} \mathrm{~N}_{2} \mathrm{O}_{6} \mathrm{Si}+\mathrm{Na}, 533.2084$; found, 533.2099.

(R)-3-((S,Z)-6-Nitro-5-(o-tolyl)-2-((triethylsilyl)oxy)hex-2-enoyl)-4-phenyloxazolidin-2one (3b): The title compound was prepared according to the general procedure using imide 1 (50.0 mg, $0.150 \mathrm{mmol}, 1.0$ equiv), nitroalkene $2 \mathbf{b}^{28 \mathrm{a}}$ (38.0 mg, $0.225 \mathrm{mmol}, 1.5 \mathrm{equiv}$ ), and vinylmagnesium bromide $(0.23 \mathrm{~mL}, 0.230 \mathrm{mmol}, 1.5$ equiv), affording $44.0 \mathrm{mg}(56 \%)$ of the product as a yellow oil. Analytical data for 3b: IR (thin film, $\mathrm{cm}^{-1}$ ) 2877, 2360, 1788, 1380, 1204, 746, 528; ${ }^{1} \mathrm{H} \mathrm{NMR}\left(600 \mathrm{MHz}, \mathrm{CDCl}_{3}\right)$ 7.34-7.18 (m, 9H), 5.46-5.38 (m, 2H), $4.70-4.61(\mathrm{~m}, 3 \mathrm{H}), 4.23-4.21(\mathrm{~m}, 1 \mathrm{H}), 3.95-3.90(\mathrm{~m}, 1 \mathrm{H}), 2.67-2.62(\mathrm{~m}, 1 \mathrm{H}), 2.50-2.45$ $(\mathrm{m}, 1 \mathrm{H}), 2.32(\mathrm{~s}, 3 \mathrm{H}), 0.93-0.90(\mathrm{~m}, 9 \mathrm{H}), 0.64-0.60(\mathrm{~m}, 6 \mathrm{H}) ;{ }^{13} \mathrm{C}$ NMR $\left(125 \mathrm{MHz}, \mathrm{CDCl}_{3}\right)$ $\delta 166.0,153.1,144.7,137.4,137.1,136.3,131.0,129.2,129.0,127.4,126.7,126.4,125.5$, $118.1,79.1,69.8,58.5,38.4,29.2,19.5,6.6,5.1$; TLC (30\% EtOAc/hexanes) $R_{f} 0.51$; HRMS (ESI ${ }^{+}$) calcd for $\mathrm{C}_{28} \mathrm{H}_{36} \mathrm{~N}_{2} \mathrm{O}_{6} \mathrm{Si}+\mathrm{H}, 525.2421$; found, 525.2426. 
(R)-3-((S,Z)-6-Nitro-5-(p-tolyl)-2-((triethylsilyl)oxy)hex-2-enoyl)-4-phenyloxazolidin-2one (3c): The title compound was prepared according to the general procedure using imide $\mathbf{1}$ (50.0 $\mathrm{mg}, 0.150 \mathrm{mmol}, 1.0$ equiv), nitroalkene $2 \mathrm{c}^{28 \mathrm{a}}$ ( $38.0 \mathrm{mg}, 0.225 \mathrm{mmol}, 1.5$ equiv), and vinylmagnesium bromide $(0.23 \mathrm{~mL}, 0.230 \mathrm{mmol}, 1.5$ equiv), affording $45.0 \mathrm{mg}(57 \%)$ of the product as a yellow oil. Analytical data for 3c: IR (thin film, $\mathrm{cm}^{-1}$ ) 3032, 2956, 2915, 2877, 1787, 1693, 1552, 1458, 1320, 1204, 746, 701; ${ }^{1} \mathrm{H}$ NMR (600 MHz, CDCl 3 ) 7.39-7.11 (m, 9H), 5.50-5.47 (m, 2H), 4.73-4.69 (m, 2H), 4.63-4.60 (m, 1H), 4.27-4.24 (m, 1H), 2.70$2.65(\mathrm{~m}, 1 \mathrm{H}), 2.55-2.50(\mathrm{~m}, 2 \mathrm{H}), 2.37(\mathrm{~s}, 3 \mathrm{H}), 0.96-0.93(\mathrm{~m}, 9 \mathrm{H}), 0.67-0.63(\mathrm{~m}, 6 \mathrm{H}) ;{ }^{13} \mathrm{C}$ NMR (125 MHz, $\left.\mathrm{CDCl}_{3}\right) \delta 153.1,144.6,137.4,137.1,136.3,129.7,129.2,129.1,127.2$, 126.5, 118.4, 79.7, 69.9, 58.5, 43.3, 29.7, 21.1, 6.6, 5.1; TLC (30\% EtOAc/hexanes) $R_{f} 0.50$; HRMS (ESI ${ }^{+}$) calcd for $\mathrm{C}_{28} \mathrm{H}_{36} \mathrm{~N}_{2} \mathrm{O}_{6} \mathrm{Si}+\mathrm{Na}, 547.2240$; found, 547.2262.

\section{(R)-3-((S,Z)-5-(o-Chlorophenyl)-6-nitro-2-((triethylsilyl)oxy)hex-2-enoyl)-4-}

phenyloxazolidin-2-one (3d): The title compound was prepared according to the general procedure using imide 1 (50.0 mg, $0.150 \mathrm{mmol}, 1.0$ equiv), nitroalkene $2 \mathbf{d}^{28 \mathrm{~b}}(41.0 \mathrm{mg}$, $0.225 \mathrm{mmol}, 1.5$ equiv), and vinylmagnesium bromide ( $0.23 \mathrm{~mL}, 0.230 \mathrm{mmol}, 1.5$ equiv), affording $35.0 \mathrm{mg}$ (40\%) of the product as a yellow oil. Analytical data for 3d: IR (thin film, $\left.\mathrm{cm}^{-1}\right)$ 2957, 2877, 1786, 1693, 1551, 1381, 1320, 1204, 1064, 1003, 747, 699; ${ }^{1} \mathrm{H}$ NMR (600 MHz, $\left.\mathrm{CDCl}_{3}\right)$ 7.40-7.23 (m, 9H), 5.46-5.40 (m, 2H), 4.79-4.70 (m, 3H), 4.25-4.19 (m, 2H), 2.69-2.63 (m, 2H), 0.92-0.89 (m, 9H), 0.63-0.59 (m, 6H); ${ }^{13} \mathrm{C} \mathrm{NMR} \mathrm{(125} \mathrm{MHz,}$ $\left.\mathrm{CDCl}_{3}\right) \delta 166.1,153.1,144.9,137.1,136.4,134.0,130.3,129.2,129.1,128.8,128.0,127.4$, $126.4,126.2,117.4,77.6,69.9,58.5,39.7,28.0,6.6,5.2 ;$ TLC (30\% EtOAc/hexanes) $R_{f}$ 0.47; HRMS ( $\mathrm{ESI}^{+}$) calcd for $\mathrm{C}_{27} \mathrm{H}_{33} \mathrm{ClN}_{2} \mathrm{O}_{6} \mathrm{Si}+\mathrm{Na}, 567.1694$; found, 567.1707.

(R)-3-((S,Z)-5-(p-Chlorophenyl)-6-nitro-2-((triethylsilyl)oxy)hex-2-enoyl)-4phenyloxazolidin-2-one (3e): The title compound was prepared according to the general procedure using imide 1 (50.0 mg, $0.150 \mathrm{mmol}, 1.0$ equiv), nitroalkene $2 \mathrm{e}^{28 \mathrm{~b}}$ (41.0 mg, $0.225 \mathrm{mmol}, 1.5$ equiv), and vinylmagnesium bromide ( $0.23 \mathrm{~mL}, 0.230 \mathrm{mmol}, 1.5$ equiv), affording $49.0 \mathrm{mg}(60 \%)$ of the product isolated as a yellow oil. Analytical data for 3e: IR (thin film, $\mathrm{cm}^{-1}$ ) 2957, 2360, 1791, 1698, 1557, 1038, 700, 536; ${ }^{1} \mathrm{H}$ NMR (600 MHz, $\left.\mathrm{CDCl}_{3}\right) \delta 7.37-7.26(\mathrm{~m}, 7 \mathrm{H}), 7.14(\mathrm{~d}, J=9.0 \mathrm{~Hz}, 2 \mathrm{H}), 5.45(\mathrm{dd}, J=8.4,7.2,1 \mathrm{H}), 5.38(\mathrm{q}$, $7.2 \mathrm{~Hz}, 1 \mathrm{H}), 4.72-4.68(\mathrm{~m}, 1 \mathrm{H}) 4.61-4.59(\mathrm{~m}, 1 \mathrm{H}), 4.27-4.24(\mathrm{~m}, 1 \mathrm{H}), 3.61-3.56(\mathrm{~m}, 1 \mathrm{H})$, $2.60-2.50(\mathrm{~m}, 2 \mathrm{H}), 0.92-0.89(\mathrm{~m}, 9 \mathrm{H}), 0.61-0.59(\mathrm{~m}, 6 \mathrm{H}) ;{ }^{13} \mathrm{C} \mathrm{NMR}\left(150 \mathrm{MHz}, \mathrm{CDCl}_{3}\right) \delta$ 165.9, 153.1, 144.9, 137.8, 137.1, 133.6, 129.2, 129.2, 129.1, 128.7, 126.5, 117.2, 79.2, 69.9, 58.5, 42.9, 29.5, 6.6, 5.2; TLC (30\% EtOAc/hexanes) $R_{f} 0.50$; $\mathrm{HRMS}_{\left(\mathrm{ESI}^{+}\right) \text {calcd for }}$ $\mathrm{C}_{27} \mathrm{H}_{33} \mathrm{ClN}_{2} \mathrm{O}_{6} \mathrm{Si}+\mathrm{Na}$, 567.1694; found, 567.1710.

(R)-3-((S,Z)-5-(Benzo[d][1,3]dioxol-5-yl)-6-nitro-2-((triethylsilyl)-oxy)-hex-2-enoyl)-4phenyloxazolidin-2-one (3f): The title compound was prepared according to the general procedure using imide $\mathbf{1}$ (50.0 $\mathrm{mg}, 0.150 \mathrm{mmol}, 1.0$ equiv), nitroalkene $\mathbf{2} \mathbf{f}^{28 \mathrm{c}}$ (44.0 $\mathrm{mg}$, $0.225 \mathrm{mmol}, 1.5$ equiv), and vinylmagnesium bromide ( $0.23 \mathrm{~mL}, 0.230 \mathrm{mmol}, 1.5$ equiv), affording $46.0 \mathrm{mg}(55 \%)$ of the product as a yellow oil. Analytical data for 3f: IR (thin film, $\left.\mathrm{cm}^{-1}\right)$ 2956, 2877, 2360, 1785, 1694, 1248, 1204, 1040, 745, 701; ${ }^{1} \mathrm{H}$ NMR (600 MHz, $\left.\mathrm{CDCl}_{3}\right) 7.39-7.27(\mathrm{~m}, 5 \mathrm{H}), 6.61(\mathrm{~d}, J=8.4 \mathrm{~Hz}, 1 \mathrm{H}), 6.68-6.64(\mathrm{~m}, 2 \mathrm{H}), 5.95(\mathrm{~s}, 2 \mathrm{H}), 5.47-$ $5.42(\mathrm{~m}, 2 \mathrm{H}), 4.70(\mathrm{t}, J=3.0 \mathrm{~Hz}, 1 \mathrm{H}), 4.65-4.62(\mathrm{~m}, 1 \mathrm{H}), 4.55-4.51(\mathrm{~m}, 1 \mathrm{H}), 4.26-4.22(\mathrm{~m}$, 
$1 \mathrm{H}), 3.53-3.49(\mathrm{~m}, 1 \mathrm{H}), 2.62-2.59(\mathrm{~m}, 1 \mathrm{H}), 2.46-2.44(\mathrm{~m}, 1 \mathrm{H}), 0.92-0.90(\mathrm{~m}, 9 \mathrm{H}), 0.63-$ 0.59 (m, 6H); ${ }^{13} \mathrm{C}$ NMR $\left(125 \mathrm{MHz}, \mathrm{CDCl}_{3}\right) \delta 166.0,153.1,148.1,147.1,144.7,137.1$, 133.0, 129.2, 129.1, 126.5, 120.7, 118.1, 107.5, 101.2, 79.8, 69.9, 58.5, 43.4, 29.7, 6.6, 5.1; TLC (30\% EtOAc/hexanes) $R_{f} 0.47$; HRMS $\left(\mathrm{ESI}^{+}\right.$) calcd for $\mathrm{C}_{28} \mathrm{H}_{34} \mathrm{~N}_{2} \mathrm{O}_{8} \mathrm{Si}+\mathrm{Na}, 577.1982$; found, 577.1995.

(R)-3-((R,Z)-5-(Thiophen-2-yl)-2-((triethylsilyl)oxy)hex-2-enoyl)-4-phenyloxazolidin-2one (3g): The title compound was prepared according to the general procedure using imide 1 (50.0 mg, $0.150 \mathrm{mmol}, 1.0$ equiv), nitroalkene $2 \mathrm{~g}^{28 \mathrm{a}}$ ( $35.0 \mathrm{mg}, 0.225 \mathrm{mmol}, 1.5$ equiv), and vinylmagnesium bromide ( $0.23 \mathrm{~mL}, 0.230 \mathrm{mmol}, 1.5$ equiv), affording $42.0 \mathrm{mg}(54 \%)$ of the product isolated as a yellow oil. Analytical data for 3g: IR (thin film, $\mathrm{cm}^{-1}$ ) 2957, 2877, 2360, 1785, 1695, 1379, 1204, 1013, 744, 700; ${ }^{1} \mathrm{H} \mathrm{NMR}\left(600 \mathrm{MHz}, \mathrm{CDCl}_{3}\right) \delta 7.37-$ $7.23(\mathrm{~m}, 6 \mathrm{H}), 6.97-6.96(\mathrm{~m}, 1 \mathrm{H}), 6.90(\mathrm{~d}, J=3 \mathrm{~Hz}, 1 \mathrm{H}), 5.51-5.46(\mathrm{~m}, 2 \mathrm{H}), 4.72-4,69(\mathrm{~m}$, 2H), 4.61-4.59 (m, 1H), 3.99-3.92 (m, 1H), 2.66-2.63 (m, 2H), 0.93-0.90 (m, 9H), 0.64$0.60(\mathrm{~m}, 6 \mathrm{H}) ;{ }^{13} \mathrm{C}$ NMR $\left(150 \mathrm{MHz}, \mathrm{CDCl}_{3}\right) \delta 166.0,153.1,145.0,142.3,137.1,129.2$ $129.1,127.1,126.5,125.3,124.6,117.3,79.9,69.9,58.5,39.0,30.4,6.6,5.2$; TLC (30\% EtOAc/hexanes) $R_{f} 0.36$; LRMS (ESI+) calcd for $\mathrm{C}_{25} \mathrm{H}_{32} \mathrm{~N}_{2} \mathrm{O}_{6} \mathrm{SSi}+\mathrm{Na}$, 539.17; found, 539.26 .

\section{(R)-3-((R,Z)-5-(Furan-2-yl)-6-nitro-2-((triethylsilyl)oxy)hex-2-enoyl)-4-} phenyloxazolidin-2-one (3h): The title compound was prepared according to the general procedure using imide 1 (50.0 mg, $0.150 \mathrm{mmol}, 1.0$ equiv), nitroalkene $2 \mathbf{h}^{28 \mathrm{~b}}(32.0 \mathrm{mg}$, $0.225 \mathrm{mmol}, 1.5$ equiv), and vinylmagnesium bromide ( $0.23 \mathrm{~mL}, 0.230 \mathrm{mmol}, 1.5$ equiv), affording $49.0 \mathrm{mg}(65 \%)$ of the product isolated as an orange oil. Analytical data for $\mathbf{3 h}$ : IR (thin film, $\mathrm{cm}^{-1}$ ) 2957, 2877, 2360, 2341, 1787, 1693, 1555, 1379, 1321, 1204, 746, 700; ${ }^{1} \mathrm{H}$ NMR $\left(600 \mathrm{MHz}, \mathrm{CDCl}_{3}\right) \delta 7.37-7.30(\mathrm{~m}, 7 \mathrm{H}), 6.32(\mathrm{~d}, J=1.8 \mathrm{~Hz}, 1 \mathrm{H}), 6.31(\mathrm{~d}, J=1.8 \mathrm{~Hz}$, $1 \mathrm{H}), 6.15-6.14(\mathrm{~m}, 1 \mathrm{H}), 5.50-5.45(\mathrm{~m}, 3 \mathrm{H}), 4.72-4.71(\mathrm{~m}, 1 \mathrm{H}), 4.26-4.23(\mathrm{~m}, 1 \mathrm{H}), 2.62-$ 2.61 (m, 2H), 0.92-0.89 (m, 9H), 0.63-0.59 (m, 6H); $\left.{ }^{13} \mathrm{C} \mathrm{NMR} \mathrm{(125} \mathrm{MHz,} \mathrm{CDCl}_{3}\right) \delta$ 166.0, 153.2, 152.2, 144.9, 142.3, 137.0, 129.2, 129.1, 126.5, 117.7, 110.4, 107.1, 69.9, 58.5, 37.2, 27.1, 6.6, 5.1; TLC (30\% EtOAc/hexanes) $R_{f} 0.44$; HRMS (ESI ${ }^{+}$) calcd for $\mathrm{C}_{25} \mathrm{H}_{32} \mathrm{~N}_{2} \mathrm{O}_{7} \mathrm{Si}$ $+\mathrm{Na}, 523.1876$; found, 523.1893 .

(R)-3-((S,2Z,6E)-5-(Nitromethyl)-7-phenyl-2-((triethylsilyl)oxy)-hepta-2,6-dienoyl)-4phenyloxazolidin-2-one (3i): The title compound was prepared according to the general procedure using imide $\mathbf{1}$ (50.0 mg, $0.150 \mathrm{mmol}, 1.0$ equiv), nitroalkene $2 \mathbf{2}^{28 \mathrm{~b}}$ (39.4 mg, $0.225 \mathrm{mmol}, 1.5$ equiv), and vinylmagnesium bromide ( $0.23 \mathrm{~mL}, 0.230 \mathrm{mmol}, 1.5$ equiv), affording $55.5 \mathrm{mg}(69 \%)$ of the product as a yellow oil. Analytical data for 3i: IR (thin film, $\left.\mathrm{cm}^{-1}\right)$ 2955, 2359, 1791, 1623, 1507, 1331, 1205, 742, 535; ${ }^{1} \mathrm{H}$ NMR (600 MHz, $\left.\mathrm{CDCl}_{3}\right)$ 7.37-7.25 (m, 10H), $6.98(\mathrm{~d}, J=16.2 \mathrm{~Hz}, 1 \mathrm{H}), 6.09-6.08(\mathrm{~m}, 1 \mathrm{H}), 5.60-5.57(\mathrm{~m}, 1 \mathrm{H}), 5.48-$ $5.42(\mathrm{~m}, 1 \mathrm{H}), 4.71(\mathrm{t}, J=3.0 \mathrm{~Hz}, 1 \mathrm{H}), 4.53-4.52(\mathrm{~m}, 1 \mathrm{H}), 4.52(\mathrm{~d}, J=9.0 \mathrm{~Hz}, 1 \mathrm{H}), 4.26-$ $4.24(\mathrm{~m}, 1 \mathrm{H}), 2.45-2.34(\mathrm{~m}, 1 \mathrm{H}), 2.46-2.42(\mathrm{~m}, 1 \mathrm{H}), 0.90-0.89(\mathrm{~m}, 9 \mathrm{H}), 0.63-0.59(\mathrm{~m}$, $6 \mathrm{H}) ;{ }^{13} \mathrm{C}$ NMR $\left(125 \mathrm{MHz}, \mathrm{CDCl}_{3}\right) \delta 166.1,153.2,144.7,137.1,136.3,133.3,129.2,129.1$, 128.6, 127.9, 127.1, 126.5, 118.1, 79.0, 69.9, 58.6, 41.7, 28.4, 6.7, 5.1; TLC (30\% EtOAc/ hexanes) $R_{f} 0.47$; HRMS (ESI ${ }^{+}$) calcd for $\mathrm{C}_{29} \mathrm{H}_{36} \mathrm{~N}_{2} \mathrm{O}_{6} \mathrm{SiNa}$, 559.2240; found, 559.2255. 
(R)-3-((R,Z)-5-(Nitromethyl)-2-((triethylsilyl)oxy)hept-2-enoyl)-4-phenyloxazolidin-2one (3j): The title compound was prepared according to the general procedure using imide 1 (50.0 $\mathrm{mg}, 0.150 \mathrm{mmol}, 1.0$ equiv), nitroalkene $2 \mathbf{j}^{28 \mathrm{c}}$ ( $23.0 \mathrm{mg}, 0.225 \mathrm{mmol}, 1.5$ equiv), and vinylmagnesium bromide $(0.23 \mathrm{~mL}, 0.230 \mathrm{mmol}, 1.5$ equiv), affording $35.0 \mathrm{mg}(51 \%)$ of the product isolated as a clear oil. Analytical data for 3j: IR (thin film, $\mathrm{cm}^{-1}$ ) 2959, 2877, 1789, 1696, 1002, 744, 700, 533; ${ }^{1} \mathrm{H}$ NMR $\left(600 \mathrm{MHz}, \mathrm{CDCl}_{3}\right) \delta 7.40-7.33(\mathrm{~m}, 5 \mathrm{H}), 5.60-5.57$ (m, $1 \mathrm{H}), 5.50-5.47(\mathrm{~m}, 1 \mathrm{H}), 4.72(\mathrm{t}, J=9 \mathrm{~Hz}, 1 \mathrm{H}), 4.38-4.32(\mathrm{~m}, 2 \mathrm{H}), 4.28-4.25(\mathrm{~m}, 1 \mathrm{H}), 2.40-$ $2.17(\mathrm{~m}, 3 \mathrm{H}) 1.45(\mathrm{q}, J=7.2 \mathrm{~Hz}, 2 \mathrm{H}), 0.98-0.89(\mathrm{~m}, 12 \mathrm{H}), 0.63-0.59(\mathrm{~m}, 6 \mathrm{H}) ;{ }^{13} \mathrm{C}$ NMR $\left(150 \mathrm{MHz}, \mathrm{CDCl}_{3}\right) \delta 166.1,153.3,144.6,137.1,129.2$ 129.1, 126.4, 119.3, 78.6, 69.8, 58.6, 39.1, 26.9, 24.4, 10.8, 6.6, 5.2; TLC (20\% EtOAc/hexanes) $R_{f} 0.32$; HRMS (ESI ${ }^{+}$) calcd for $\mathrm{C}_{23} \mathrm{H}_{34} \mathrm{~N}_{2} \mathrm{O}_{6} \mathrm{Si}+\mathrm{Na}, 485.2084$; found, 485.2092.

\section{(R)-3-((S,Z)-6-Methyl-5-(nitromethyl)-2-((triethylsilyl)oxy)hept-2-enoyl)-4-}

phenyloxazolidin-2-one (3k): The title compound was prepared according to the general procedure using imide 1 ( $50.0 \mathrm{mg}, 0.150 \mathrm{mmol}, 1.0$ equiv), nitroalkene $\mathbf{2} \mathbf{k}^{28 \mathrm{c}}(29.0 \mathrm{mg}$, $0.225 \mathrm{mmol}, 1.5$ equiv), and vinylmagnesium bromide ( $0.23 \mathrm{~mL}, 0.230 \mathrm{mmol}, 1.5$ equiv), affording $34.5 \mathrm{mg}$ (71\%) of the product as a pale yellow oil. Analytical data for 3k: IR (thin film, $\mathrm{cm}^{-1}$ ) 2459, 2877, 2360, 1788, 1693, 1550, 1383, 1205, 1004, 745, 700; ${ }^{1} \mathrm{H}$ NMR (600 $\left.\mathrm{MHz}, \mathrm{CDCl}_{3}\right) \delta 7.40-7.33(\mathrm{~m}, 5 \mathrm{H}), 5.60-5.58(\mathrm{~m}, 1 \mathrm{H}), 5.50-5.47(\mathrm{~m}, 1 \mathrm{H}), 4.36-4.34(\mathrm{~m}$, $1 \mathrm{H}), 4.31-4.25(\mathrm{~m}, 3 \mathrm{H}), 2.39-2.15(\mathrm{~m}, 3 \mathrm{H}), 1.88-1.68(\mathrm{~m}, 1 \mathrm{H}), 0.95-0.88(\mathrm{~m}, 15 \mathrm{H}), 0.62-$ $0.58(\mathrm{~m}, 6 \mathrm{H}) ;{ }^{13} \mathrm{C} \mathrm{NMR}\left(125 \mathrm{MHz}, \mathrm{CDCl}_{3}\right) \delta 166.1,153.3,144.7,137.0$ 129.2, 129.1, $126.5,120.3,69.9,58.7,41.7,28.4,6.7,5.1$; TLC (30\% EtOAc/hexanes) $R_{f} 0.59$; HRMS (ESI) calcd for $\mathrm{C}_{24} \mathrm{H}_{36} \mathrm{~N}_{2} \mathrm{O}_{6} \mathrm{Si}+\mathrm{H}, 477.2421$; found, 477.2451 .

(R)-3-((R,Z)-7-Methyl-5-(nitromethyl)-2-((triethylsilyl)oxy)oct-2-enoyl)-4phenyloxazolidin-2-one (31): The title compound was prepared according to the general procedure using imide $\mathbf{1}\left(50.0 \mathrm{mg}, 0.150 \mathrm{mmol}, 1.0\right.$ equiv), nitroalkene $2 \mathbf{I}^{28 \mathrm{~b}}(29.0 \mathrm{mg}$, $0.225 \mathrm{mmol}, 1.5$ equiv), and vinylmagnesium bromide ( $0.23 \mathrm{~mL}, 0.230 \mathrm{mmol}, 1.5$ equiv), affording $45.0 \mathrm{mg}$ (62\%) of the product isolated as a clear oil. Analytical data for 31: IR (thin film, $\left.\mathrm{cm}^{-1}\right) 2957,2876,1787,1693,1383,1205,745,700 ;{ }^{1} \mathrm{H} \mathrm{NMR}\left(600 \mathrm{MHz}, \mathrm{CDCl}_{3}\right) \delta$ $7.40-7.33(\mathrm{~m}, 5 \mathrm{H}), 5.59(\mathrm{t}, J=13.0 \mathrm{~Hz}, 1 \mathrm{H}), 4.82(\mathrm{dd}, J=8.4,7.8 \mathrm{~Hz}, 1 \mathrm{H}), 4.72(\mathrm{t}, J=9.0$ $\mathrm{Hz}, 1 \mathrm{H}), 4.36-4.25(\mathrm{~m}, 3 \mathrm{H}), 2.41-2.38(\mathrm{~m}, 2 \mathrm{H}), 2.18-2.16(\mathrm{~m}, 1 \mathrm{H}), 1.67-1.66(\mathrm{~m}, 1 \mathrm{H})$, 1.38-1.15 (m, 2H), 0.92-0.89 (m, 15H), 0.63-0.59 (m, 6H); ${ }^{13} \mathrm{C} \mathrm{NMR}\left(150 \mathrm{MHz}, \mathrm{CDCl}_{3}\right) \delta$ 166.1, 153.2, 144.6, 137.2, 129.2, 129.0, 126.4, 119.1, 79.1, 69.8, 58.6, 40.9, 35.5, 27.6, 25.1, 22.7, 22.3, 6.7, 6.6, 5.2, 5.2; TLC (20\% EtOAc/hexanes) $R_{f} 0.39$; $\mathrm{HRMS}_{\left(\mathrm{ESI}^{+}\right) \text {calcd }}$ for $\mathrm{C}_{25} \mathrm{H}_{38} \mathrm{~N}_{2} \mathrm{O}_{6} \mathrm{Si}+\mathrm{H}, 491.2577$; found, 491.2600 .

\section{(S)-4-Nitro-3-phenylbutanal}

A $20 \mathrm{~mL}$ scintillation vial was charged with $3 \mathbf{a}$ ( $35 \mathrm{mg}, 0.069 \mathrm{mmol}, 1.0$ equiv) and $\mathrm{CH}_{2} \mathrm{Cl}_{2}$ $(1.0 \mathrm{~mL}, 0.07 \mathrm{M})$. Ozone was bubbled through the solution at $-78{ }^{\circ} \mathrm{C}$ until the solution turned a light blue. The reaction was then purged with $\mathrm{N}_{2}$ for 15 min until the color dissipated. Dimethyl sulfide ( $0.08 \mathrm{mg}, 0.135 \mathrm{mmol}, 5.0$ equiv) was added to the reaction mixture and warmed to room temperature. Once the reaction was complete, the solution was diluted with $\mathrm{CH}_{2} \mathrm{Cl}_{2}(5 \mathrm{~mL})$ and $\mathrm{H}_{2} \mathrm{O}(5 \mathrm{~mL})$. The layers were separated, and the aqueous layer was extracted with methylene chloride $(3 \times 5 \mathrm{~mL})$. The combined organic extracts 
were washed with brine $(5 \mathrm{~mL})$, dried with sodium sulfate, and concentrated in vacuo. The crude mixture was purified by flash chromatography (30\% EtOAc/hexanes) to provide 13.4 $\mathrm{mg}(52 \%)$ of the product as a colorless oil. ${ }^{1} \mathrm{H}$ NMR spectral data matched those reported for the title compound, ${ }^{24 a}[\mathrm{a}]_{\mathrm{D}}-24\left(c 0.71, \mathrm{CHCl}_{3}\right)$.

\section{(S)-4-Nitro-3-phenylbutan-1-ol}

A $20 \mathrm{~mL}$ scintillation vial was charged with $3 \mathbf{a}$ (14 $\mathrm{mg}, 0.027 \mathrm{mmol}, 1.0$ equiv) and $\mathrm{CH}_{2} \mathrm{Cl}_{2}$ $(1.0 \mathrm{~mL}, 0.03 \mathrm{M})$. Ozone was bubbled through the solution at $-78{ }^{\circ} \mathrm{C}$ until the solution turned a light blue. The reaction was then purged with $\mathrm{N}_{2}$ for 15 min until the color dissipated. $\mathrm{NaBH}_{4}(3.11 \mathrm{mg}, 0.082 \mathrm{mmol}, 3.0$ equiv) was added, and the reaction was warmed to room temperature. Once the reaction was complete, the solution was diluted with $\mathrm{CH}_{2} \mathrm{Cl}_{2}(5 \mathrm{~mL})$ and $\mathrm{H}_{2} \mathrm{O}(5 \mathrm{~mL})$. The layers were separated, and the aqueous layer was extracted with methylene chloride $(3 \times 5 \mathrm{~mL})$. The combined organic extracts were washed with brine $(5 \mathrm{~mL})$, dried with sodium sulfate, and concentrated in vacuo. The crude mixture was purified by flash chromatography (30\% EtOAc/hexanes) to provide $4 \mathrm{mg}(75 \%)$ of the product as a colorless oil. ${ }^{1} \mathrm{H}$ NMR spectral data matched those reported for the title compound. ${ }^{24 \mathrm{~b}}$ SFC analysis showed a $96: 4$ er for the product.

\section{Supplementary Material}

Refer to Web version on PubMed Central for supplementary material.

\section{Acknowledgments}

The project described was supported by Award No. R01 GM084927 from the National Institute of General Medical Sciences.

\section{REFERENCES}

1. (a) Denmark SE, Heemstra JR, Beutner GL. Angew. Chem. Int. Ed. 2005; 44:4682-4698.(b) Kalesse M, Cordes M, Symkenberg G, Lu H-H. Nat. Prod. Rep. 2014; 31:563-594. [PubMed: 24595879]

2. Casiraghi G, Battistini L, Curti C, Rassu G, Zanardi F. Chem. Rev. 2011; 111:3076-3154. [PubMed: 21434642]

3. Schneider C, Abels F. Org. Biomol. Chem. 2014; 12:3531-3543. [PubMed: 24760480]

4. Fukui K, Yonezawa T, Nagata C, Shingu H. J. Chem. Phys. 1954; 22:1433-1442.

5. Bencivenni G, Galzerano P, Mazzanti A, Bartoli G, Melchiorre P. Proc. Natl. Acad. Sci. U. S. A. 2010; 107:20642-20647. [PubMed: 20566884]

6. Albrecht L, Dickmeiss G, Weise CF, Rodríguez-Escrich C, Jørgensen KA. Angew. Chem. Int. Ed. 2012; 51:13109-13113.

7. (a) Gupta V, Sudhir VS, Mandal T, Schneider C. Angew. Chem. Int. Ed. 2012; 51:6739-6742.(b) Basu S, Gupta V, Nickel J, Schneider C. Org. Lett. 2014; 16:274-277. [PubMed: 24341388]

8. Gu Y, Wang Y, Yu T-Y, Liang Y-M, Xu P-F. Angew. Chem. Int. Ed. 2014; 53:14128-14131. 9. Yang D, Wang L, Han F, Zhao D, Zhang B, Wang R. Angew. Chem. Int. Ed. 2013; 52:6739-6742. 10. (a) Boyce GR, Greszler SN, Johnson JS, Linghu X, Malinowski JT, Nicewicz DA, Satterfield AD, Schmitt DC, Steward KM. J. Org. Chem. 2012; 77:4503-4515. [PubMed: 22414181] (b) Boyce, GR.; Johnson, JS. tert-Butyl 2-(tert-butyldimethylsilyl)-2-oxoacetate. e-EROS Encyclopedia of Reagents for Organic Synthesis. John Wiley and Sons Ltd.; 2013.

11. Boyce GR, Johnson JS. Angew. Chem. Int. Ed. 2010; 49:8930-8933. 
12. (a) Kuwajima I, Kato M. J. Chem. Soc. Chem. Commun. 1979:708-709.(b) Reich HJ, Olson RE, Clark MC. J. Am. Chem. Soc. 1980; 102:1423-1424.(c) Kuwajima I, Kato M. Tetrahedron Lett. 1980; 21:623-626.(d) Enda J, Matsutani T, Kuwajima I. Tetrahedron Lett. 1984; 25:5307-5310. (e) Kato M, Mori A, Oshino H, Enda J, Kobayashi K, Kuwajima I. J. Am. Chem. Soc. 1984; 106:1773-1778.(f) Enda J, Kuwajima I. J. Am. Chem. Soc. 1985; 107:5495-5501.(g) Matsuoka R, Horiguchi Y, Kuwajima I. Tetrahedron Lett. 1987; 28:1299-1302.

13. Boyce GR, Liu S, Johnson JS. Org. Lett. 2012; 14:652-655. [PubMed: 22235777]

14. Schmitt DC, Johnson JS. Org. Lett. 2010; 12:944-947. [PubMed: 20143793]

15. Nicewicz DA, Johnson JS. J. Am. Chem. Soc. 2005; 127:6170-6171. [PubMed: 15853312]

16. Satterfield, AD. Ph.D. Thesis. Chapel Hill, NC: University of North Carolina; 2009.

17. Greszler SN, Malinowski JT, Johnson JS. J. Am. Chem. Soc. 2010; 132:17393-17395. [PubMed: 21087044]

18. (a) Yao M, Lu C-D. Org. Lett. 2011; 13:2782-2785. [PubMed: 21520931] (b) Jiang J-L, Yao M, Lu C-D. Org. Lett. 2014; 16:318-321. [PubMed: 24308782]

19. Al-Rashid ZF, Johnson WL, Hsung RP, Wei Y, Yao P-Y, Liu R, Zhao K. J. Org. Chem. 2008; 73:8780-8784. [PubMed: 18937407]

20. Brook AG. Acc. Chem. Res. 1974; 7:77-84.

21. Evans, DA.; Kim, AS. (S)-4-Benzyl-2-Oxazolidinone e-EROS Encyclopedia of Reagents for Organic Synthesis. John Wiley and Sons Ltd.; 2001.

22. Hamada T, Ye X, Stahl SS. J. Am. Chem. Soc. 2008; 130:833-835. [PubMed: 18166058]

23. Nicewicz DA, Brétéché G, Johnson JS. Org. Synth. 2008; 85:278-286.

24. The Supporting Information contains a more detailed explanation of the stereochemical determination and enantiomeric ratio. Gotoh H, Ishikawa H, Hayashi Y. Org. Lett. 2007; 9:53075309. [PubMed: 17997567] Palomo C, Landa A, Mielgo A, Oiarbide M, Puente A, Vera S. Angew. Chem. Int. Ed. 2007; 46:8431-8435.

25. Mikami K, Shimizu M, Zhang H-C, Maryanoff BE. Tetrahedron. 2001; 57:2917-2951.

26. (a) McNulty J, Mo R. Chem. Commun. 1998:933-934.(b) Robertson J, Hall MJ, Green SP. Org. Biomol. Chem. 2003; 1:3635-3638. [PubMed: 14649891] (c) Blidi LE, Assaf Z, Bres FC, Veschambre H, Théry V, Bolte J, Lemaire M. ChemCatChem. 2009; 1:463-471.

27. Alaimo PJ, Peters DW, Arnold J, Bergman RG. J. Chem. Educ. 2001; 78:64.

28. (a) Trost BM, Müller C. J. Am. Chem. Soc. 2008; 130:2438-2439. [PubMed: 18237176] (b) Sekikawa T, Kitaguchi T, Kitaura H, Minami T, Hatanaka Y. Org. Lett. 2015; 17:3026-3029. [PubMed: 26066417] (c) Guo C, Xue M-X, Zhu M-K, Gong L-Z. Angew. Chem. Int. Ed. 2008; 47:3414-3417. 


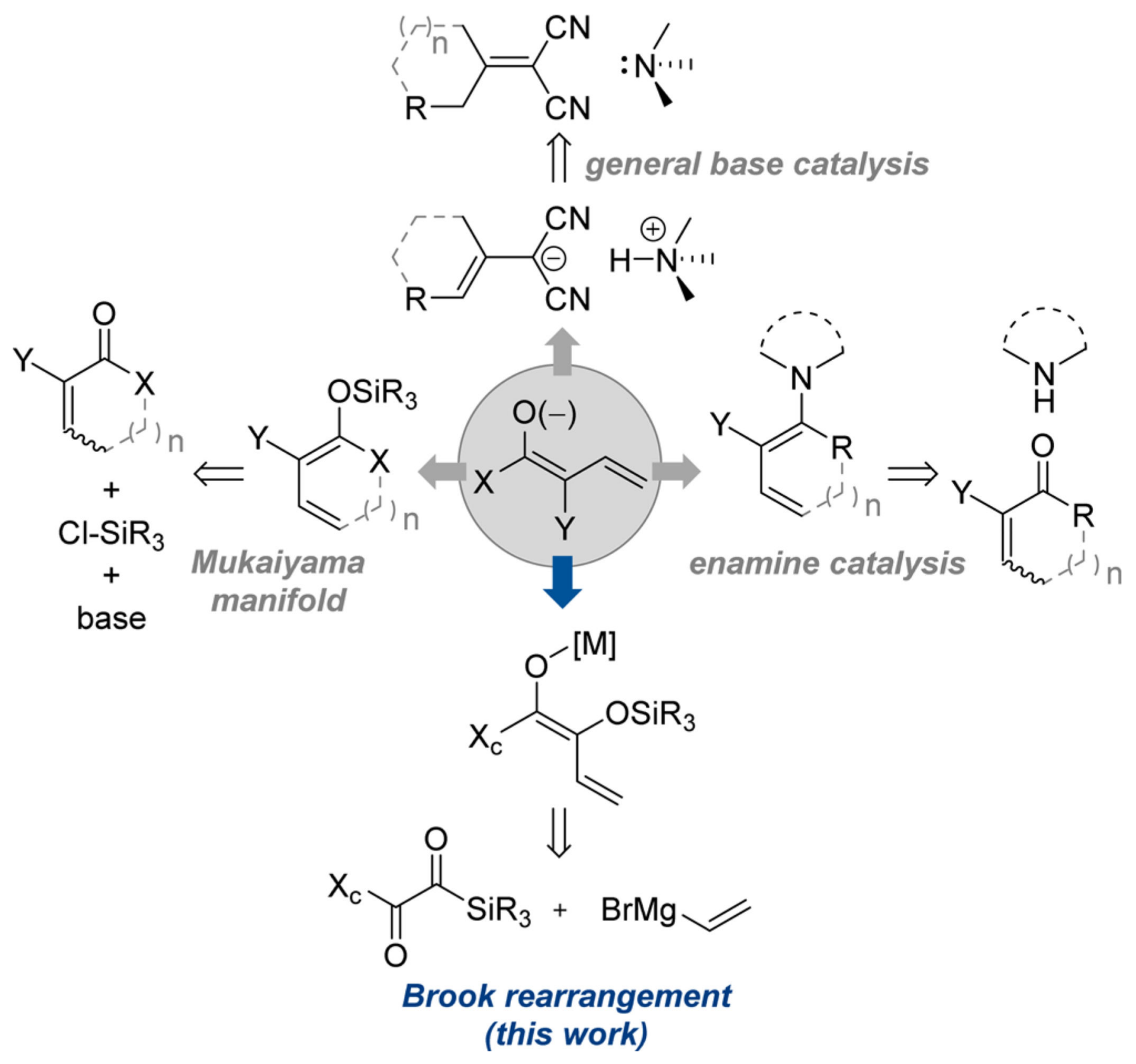

Figure 1.

Dienolate synthon: selected synthetic equivalents. 
- Diastereoselective Couplings with a Chiral Ester

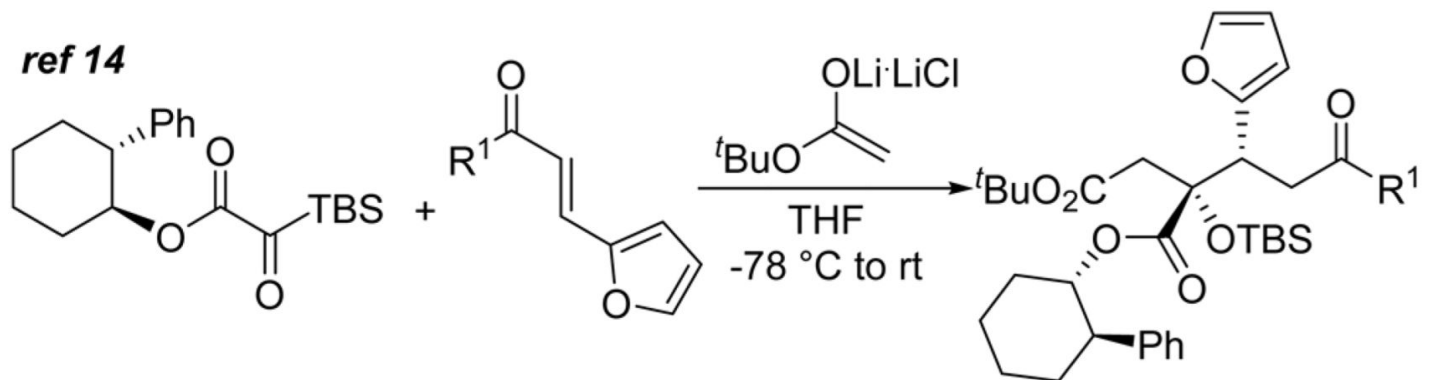

ref 16

4.8:1 dr<smiles>CC1CCC(C(C)(C)c2ccccc2)C(OC(=O)C(=O)C(C)C(C)O)C1</smiles>

- Stereoinduction with a Chiral Electrophile only example ref 17<smiles>[R]C1=C([R])C([R])C1=O</smiles>

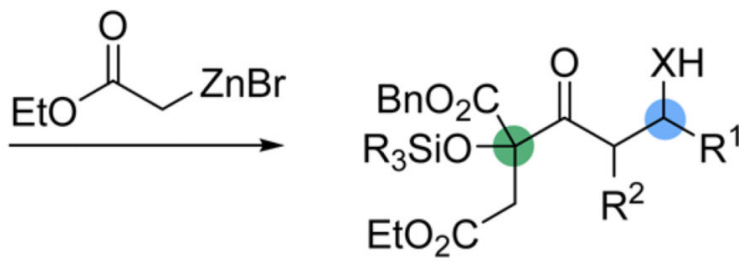

up to $>20: 1 \mathrm{dr}$<smiles>[R20]C(=O)[18O][13CH3]</smiles><smiles>C=C(OCC)[N+](=O)OCC</smiles>

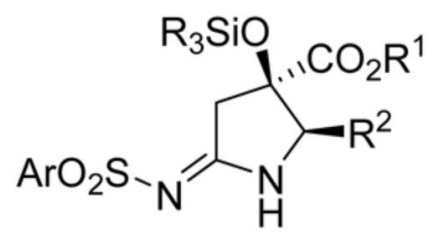

$>20: 1 \mathrm{dr}$

Figure 2.

Diastereoselective silyl glyoxylate couplings. 


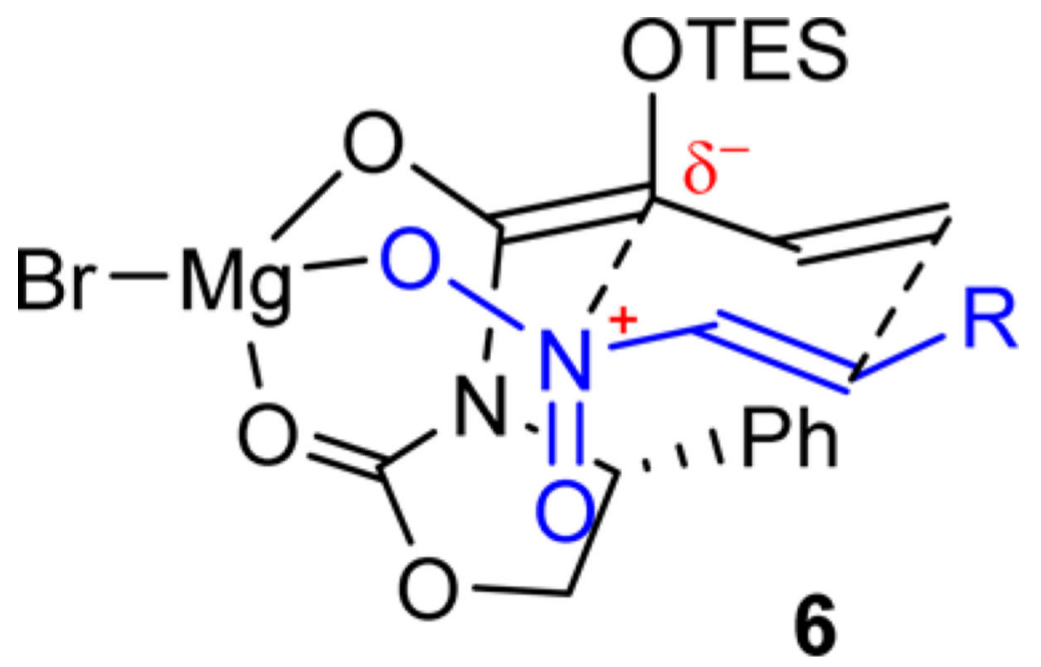

Figure 3.

Proposed trans-decalin transition state. 
<smiles>C=CN=C(C#[SH])C(=O)N1C(=O)OC[C@H]1Br</smiles>

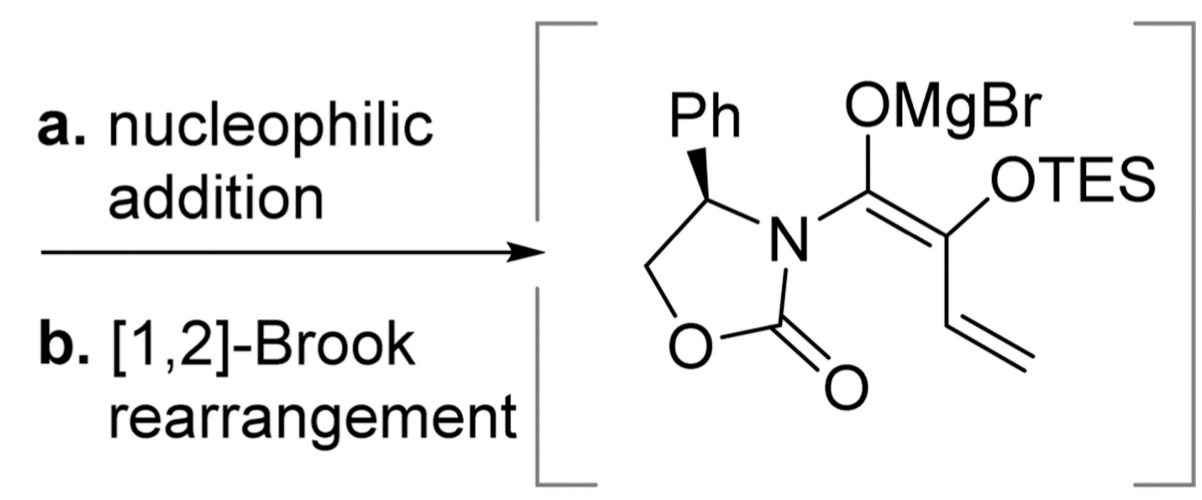<smiles>[2H][C@@H](C/C=C(\OC#[SH])C(=O)N1C(=O)OC[C@H]1P)C[N+](=O)[O-]</smiles><smiles>[R]C=C[N+](=O)CC</smiles>
transfer

Scheme 1.

Vinylmagnesium Bromide-Initiated Vinylogous Coupling of Silyl Glyoximide with Nitroalkenes 


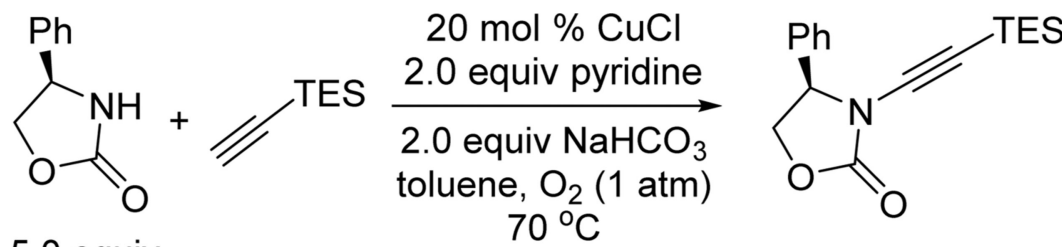

5.0 equiv $70{ }^{\circ} \mathrm{C}$
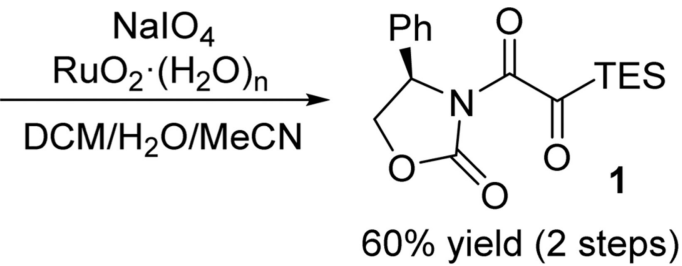

Scheme 2.

Optimized Synthesis of Silyl Glyoximide 1 
- reference 13:

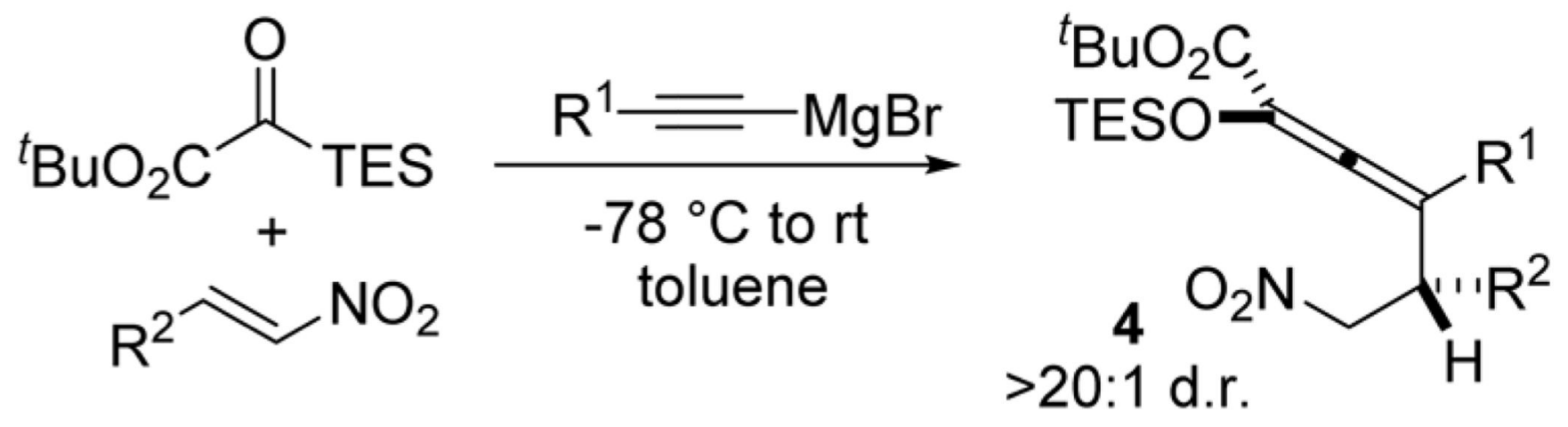

- attempted extension:

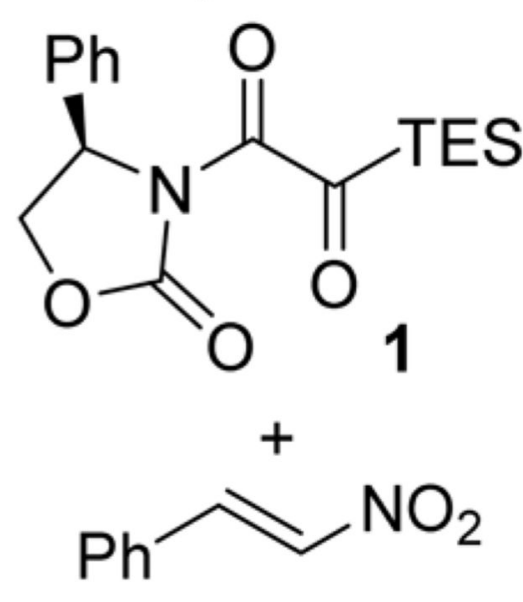

2a

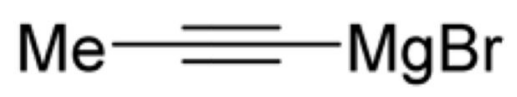

$-78^{\circ} \mathrm{C}$ to $\mathrm{rt}$ toluene

Scheme 3.

Comparison of Diastereoselectivity between Silyl Glyoxylates and Silyl Glyoximides 


\section{Table 1}

Synthesis of (Z)-Enolsilanes via Three-Component Coupling

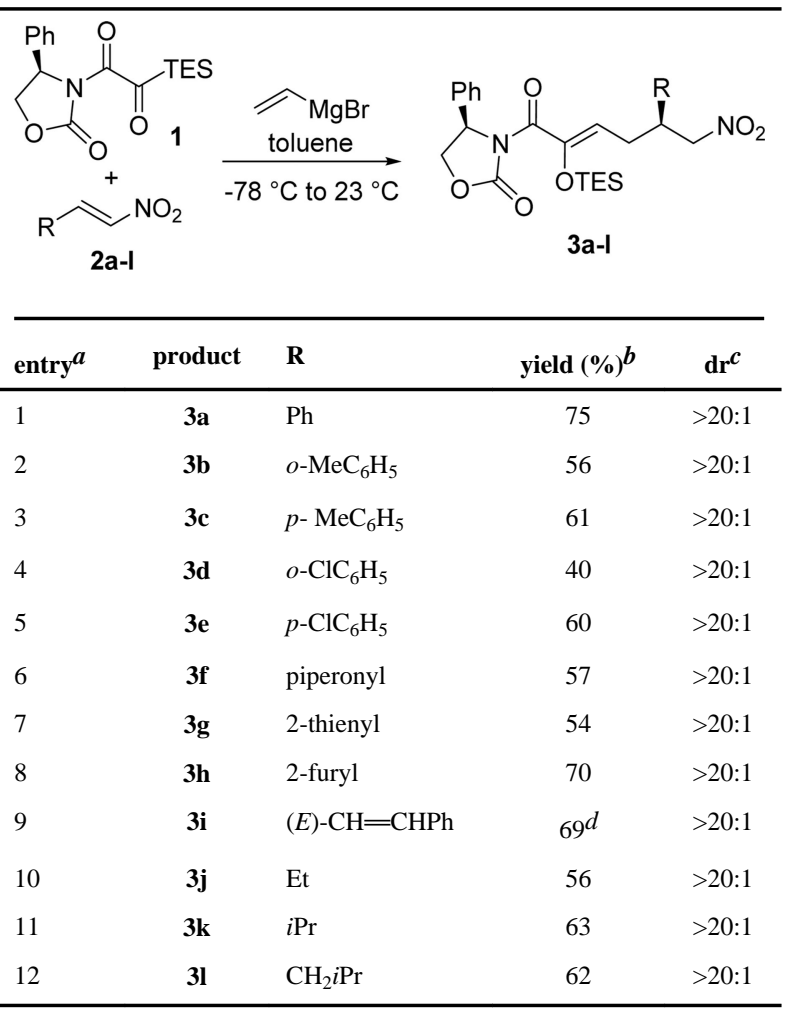

${ }^{a}$ All reactions were conducted with $[\mathbf{1}]_{0}=0.1 \mathrm{M}$.

$b_{\text {Isolated yield. }}$

${ }^{c}$ Diastereomeric ratio estimated from integration of ${ }^{1} \mathrm{H}$ NMR spectra of unpurified mixtures.

${ }^{d}$ Approximately $85 \%$ purity. 